\title{
Crop Water Requirements in Egypt Using Remote Sensing Techniques
}

\author{
Mohammed A. El-Shirbeny ${ }^{1}$, Abd-Elraouf M. Ali1, Nasser H. Saleh ${ }^{1}$ \\ National Authority for Remote Sensing and Space Sciences (Egypt) 23 Joseph Tito St., El-Nozha El-Gedida, \\ Cairo, Egypt \\ Email: $\underline{\text { mshirbeny@yahoo.com }}$
}

Received December 2013

\section{Abstract}

The common Soil in Egypt is clay soil so common irrigation system is tradition surface irrigation with $60 \%$ irrigation efficiency. Agricultural sector consumes more than $80 \%$ of water resources under surface irrigation (tradition methods). In arid and semi-arid regions consumptive use is the best index for irrigation requirements. A large part of the irrigation water applied to farm land is consumed by Evapotranspiration (ET). Irrigation water consumption under each of the physical and climatic conditions for large scale will be easier with remote sensing techniques. In Egypt, Agricultural cycle is often tow agricultural seasons yearly; summer and winter. Common summer crops are Maize, Rice and Cotton while common winter crops are Clover and Wheat. Landsat8 bands 4 and 5 provide Red (R) and Near Infra-Red (NIR) measurements and it used to calculate Normalized Deference Vegetation Index (NDVI) and monitoring cultivated areas. The cultivated land area was $3,277,311$ ha in August 2013. In this paper $K_{c}=2 * N D V I-0.2$ represents the relation between crop coefficient $\left(K_{c}\right)$ and NDVI. $K_{c}$ and Reference evapotranspiration $\left(E T_{0}\right)$ used to estimate ET $_{c}$ in Egypt. The main objective of this paper is studying the potential crop Evapotranspiration in Egypt using remote sensing techniques.

\section{Keywords}

Normalized Deference Vegetation Index (NDVI); Reference Evapotranspiration (ET ); Landsat8; Crop Coefficient $\left(\mathrm{K}_{\mathrm{c}}\right)$; Crop Evapotranspiration $\left(\mathrm{ET}_{\mathrm{c}}\right)$ and Arid Region

\section{Introduction}

Limited water resources and scarcity of water in Egypt is the main challenge for agricultural horizontal expanding policies and strategies. At the same time over population is rapidly increasing and agricultural land decreased. As a result, quantities and qualities of food decrease. To solve this problem adopted policies of horizontal and vertical expanding in agricultural lands and activities had been considered based saving irrigation water to cultivate another area. Crop water requirements must be estimated accurately, improving irrigation efficiencies and applying high efficiency irrigation method as localized irrigation (drip irrigation efficiency 85\% - 95\%), using scheduling irrigation, cultivate tolerated crops to drought, and cultivate short period verities. Information about

${ }^{*}$ Corresponding author.

How to cite this paper: El-Shirbeny, M.A., Ali, A.-E.M. and Saleh, N.H. (2014) Crop Water Requirements in Egypt Using Remote Sensing Techniques. Journal of Agricultural Chemistry and Environment, 3, 57-65.

http://dx.doi.org/10.4236/jacen.2014.32B010 
crop evapotranspiration $\left(\mathrm{ET}_{\mathrm{c}}\right.$ ) or consumptive water use is significant for water resources planning and irrigation management. Crop water requirements have to estimate with high level of certainty to save water and to maximize water unit uses. Crop evapotranspiration represent crop water requirements in consideration water involved in plant tissue structure representing about $1 \%$ or less. Reference evapotranspiration $\left(\mathrm{ET}_{\mathrm{o}}\right)$ is a key process in land surface studies. It mainly depends on water availability and incoming solar radiation and then reflects the interactions between surface water processes and climate [1]. $\mathrm{ET}_{\mathrm{c}}$, which is the consumptive water use of a field situation where the soil is not under moisture stress, can be estimated using FAO-Penman-Monteith model.

Determination of $\mathrm{ET}_{\mathrm{c}}$ at farm level has traditionally been made on the basis of a so called two steps approach. The evapotranspiration of a reference standard crop $\left(\mathrm{ET}_{\mathrm{o}}\right)$ is first estimated on the basis of a site meteorological variables. A semi-empirical coefficient (crop coefficient, $\mathrm{k}_{\mathrm{c}}$ ) is then applied to take into account all the other crop and environmental factors [2]. The standardized FAO56 Penman-Monteith model, which has been the most reasonable method in both humid and arid climatic conditions, provides ETo estimates for planning and efficient use of agricultural water resources [3] [4] and [5]. To estimate crop evapotranspiration follow equation will be used:-

$$
\mathrm{ET}_{\mathrm{c}}=\mathrm{ET}_{\mathrm{o}} * \mathrm{~K}_{\mathrm{c}}
$$

where; $\mathrm{ET}_{\mathrm{c}}$ is crop evapotranspiration (mm/day), $\mathrm{ET}_{\mathrm{o}}$ is reference evapotranspiration (mm/day), $\mathrm{K}_{\mathrm{c}}$ is crop coefficient. $\mathrm{ET}_{\mathrm{o}}$ is defined as the rate of evapotranspiration from a hypothetical reference crop with an assumed crop height of $0.12 \mathrm{~m}$, a fixed surface resistance of $70 \mathrm{~s} / \mathrm{m}$ and albedo of 0.23 closely resembling the evapotranspiration from an extensive surface of green grass of uniform height, actively growing, well watered, and completely shading the ground. A standardization of this method has been proposed by the Food and Agriculture Organization [6]. Numerous weather variables such as air temperature, relative humidity, wind speed and solar radiation required to estimate $\mathrm{ET}_{\mathrm{o}}$. Consequently, $\mathrm{ET}_{\mathrm{o}}$ is often estimated by means of empirical equations based on air temperature, relative humidity, extraterrestrial radiation and/or precipitation [7]-[9].

$$
\mathrm{ET}_{0}=\frac{0.408 \Delta\left(R_{n}-G\right)+\gamma \frac{900}{T+273} u_{2}\left(e_{s}-e_{a}\right)}{\Delta+\gamma\left(1+0.34 \mu_{2}\right)}
$$

where; $\mathrm{ET}_{\mathrm{o}}$, reference evapotranspiration $\left[\mathrm{mm} \mathrm{day}^{-1}\right], \mathrm{R}_{\mathrm{n}}$, net radiation at the crop surface $\left[\mathrm{MJ} \cdot \mathrm{m}^{-2} \cdot \mathrm{day}^{-1}\right], \mathrm{G}$, soil heat flux density $\left[\mathrm{MJ} \cdot \mathrm{m}^{-2} \cdot \mathrm{day}^{-1}\right]$, $\mathrm{T}$, mean daily air temperature at $2 \mathrm{~m}$ height $\left[{ }^{\circ} \mathrm{C}\right], \mathrm{u}_{2}$, wind speed at $2 \mathrm{~m}$ height $\left[\mathrm{m} \cdot \mathrm{s}^{-1}\right], \mathrm{e}_{\mathrm{s}}$, saturation vapour pressure $[\mathrm{kPa}], \mathrm{e}_{\mathrm{a}}$, actual vapour pressure $[\mathrm{kPa}], \mathrm{e}_{\mathrm{s}}-\mathrm{e}_{\mathrm{a}}$, saturation vapour pressure deficit $[\mathrm{kPa}]$, slope vapour pressure curve $\left[\mathrm{kPa} \cdot{ }^{\circ} \mathrm{C}^{-1}\right]$, psychrometric constant $\left[\mathrm{kPa} \cdot{ }^{\circ} \mathrm{C}^{-1}\right]$.

The crop coefficient coefficient $\left(\mathrm{K}_{\mathrm{c}}\right)$ is defined as the ratio of crop potential evapotranspiration $\left(\mathrm{ET}_{\mathrm{c}}\right)$ to a reference evapotranspiration $\left(\mathrm{ET}_{0}\right)$. It is affected by the local climate conditions, crop characteristics, length of growing season, soil moisture and the time of planting [10] and [6]. $\mathrm{ET}_{\mathrm{c}}$ can be obtained from $\mathrm{ET}_{\mathrm{o}}$ using a stage-dependent crop coefficient.

Vegetation indices (VIs) were first developed in the 1970s to monitor terrestrial landscapes by satellite sensors and have been highly successful in assessing vegetation condition, foliage, cover, phenology, and processes related to the fraction of photosynthetically active radiation absorbed by a canopy [11] and [12] [13] reported that satellite-based remote sensing is a robust, economic and efficient tool for estimating actual ET and developing crop coefficient $\left(\mathrm{K}_{\mathrm{c}}\right)$ curves. This technique can cover hundreds of sampled fields at a time so that large populations of ETo and $K_{c}$ can be used to develop representative mean values. They used empirical equation for soil adjusted vegetation index (SAVI) to get crop coefficient through the regression analysis.

$$
K_{c}=a * \mathrm{SAVI}+b
$$

where: SAVI, is soil adjusted vegetation index, a, and b, can be determined by regression analysis.

The NDVI transformation is computed as the ratio of the measured intensities in the red (R) and near infrared (NIR) spectral bands using the following formula:

$$
\mathrm{NDVI}=(\mathrm{NIR}-\mathrm{R}) /(\mathrm{NIR}+\mathrm{R})
$$

The resulting index value is sensitive to the presence of vegetation on the Earth's land surface and can be used to address issues of vegetation type, amount, and condition. Many satellites have sensors that measure the red 
and near-infrared spectral bands, and many variations on the NDVI exist. The sensor that supplies one of the most widely used NDVI products is on board the Landsat8 with channels in the red (Band 4) and near infrared (Band 5).

[14] developed a temporal upscaling scheme using satellite-derived instantaneous estimates of ET to produce a daily sum ET averaged over an 8-day interval.

[15] found that the sensitivity of NDVI to chlorophyll concentration varied depending on the choice of visible band used in the calculations. The visible band chosen, therefore, significantly changed the correlation between the NDVI and canopy properties. They also found that the NDVI tended to saturate as LAI increased. Satellite maps of vegetation show the density of plant growth. The most common measurement is called the Normalized Difference Vegetation Index (NDVI). Very low values of NDVI (0.1 and below) correspond to arid areas of rock, sand, or snow. Moderate values represent shrub and grassland (0.2 to 0.3 ), while high values indicate temperate and tropical rainforests ( 0.6 to 0.8 ). The main objective of this study is studying the potential crop Evapotranspiration in Egypt using remote sensing techniques.

\section{Materials and Methods}

\subsection{Study Area}

Nile valley and Delta, from Aswan (in the South) to Mediterranean Sea (in the North) (Figure 1).

\subsection{Remote Sensing Data Availability}

Remote sensing provides spatial coverage by measurement of reflected and emitted electromagnetic radiations, across a wide range of wavebands, from the earth's surface and surrounding atmosphere. That is mean remote sensing is the act of collecting data without physically contacting. Landsat8 data collected around 10 a.m. local time with 30 meter ground resolution, during Aug. 2013 were used in the current study. Landsat8 satellite data were used to calculate NDVI. The study area covered by 11 images (Table 1).

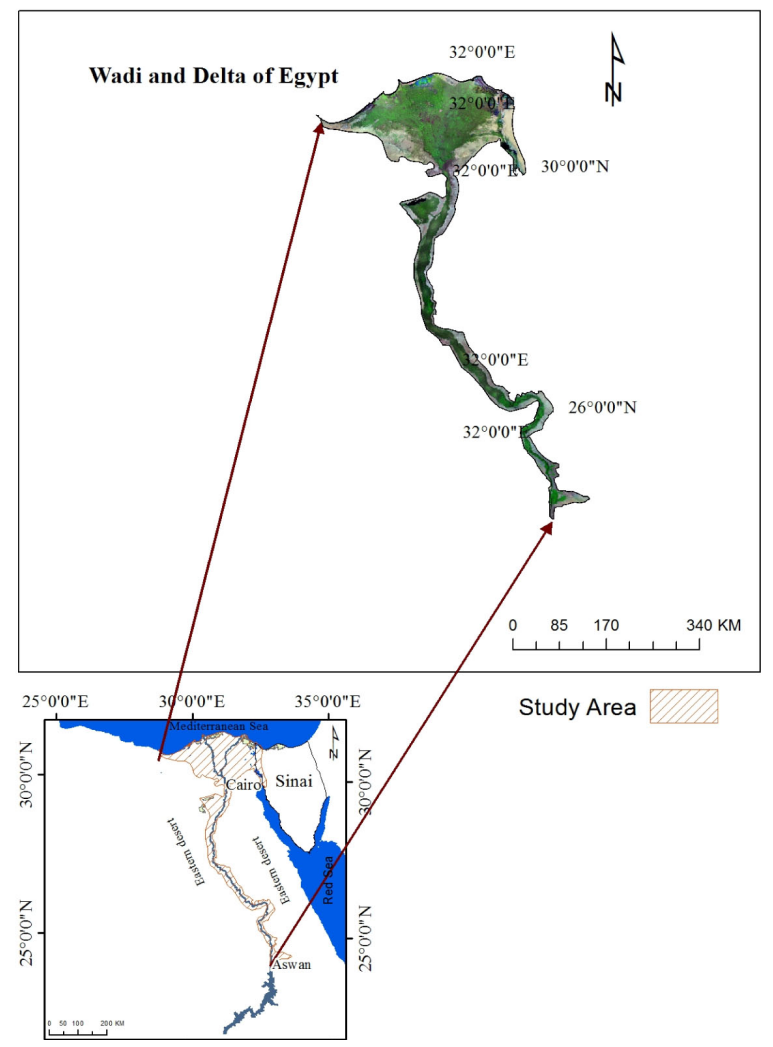

Figure 1. Study area location. 
Table 1. Used Landsat8 data to covering study area.

\begin{tabular}{cccccccc}
\hline NO & Path & Rew & Date & NO & Path & Rew & Date \\
\hline $\mathbf{1}$ & 174 & 043 & 5 Aug 2013 & $\mathbf{7}$ & 176 & 041 & 03 Aug 2013 \\
$\mathbf{2}$ & 175 & 042 & 12 Aug 2013 & $\mathbf{8}$ & 177 & 038 & 10 Aug 2013 \\
$\mathbf{3}$ & 175 & 043 & 12 Aug 2013 & $\mathbf{9}$ & 177 & 039 & 10 Aug 2013 \\
$\mathbf{4}$ & 176 & 038 & 03 Aug 2013 & $\mathbf{1 0}$ & 177 & 040 & 10 Aug 2013 \\
$\mathbf{5}$ & 176 & 039 & 03 Aug 2013 & $\mathbf{1 1}$ & 178 & 039 & 01 Aug 2013 \\
$\mathbf{6}$ & 176 & 040 & 03 Aug 2013 & & & & \\
\hline
\end{tabular}

\subsection{NDVI and Kc}

The relation between Kc and NDVI is clear. Landsat8 bands 4 and 5 provide R and NIR measurements and therefore can be used to generate NDVI data with the following formula:

$$
\text { NDVI }=(\text { Band } 5-\text { Band } 4) /(\text { Band } 5+\text { Band } 4)
$$

$\mathrm{K}_{\mathrm{c}}$ used with $\mathrm{ET}_{0}$ to estimate $\mathrm{ET}_{\mathrm{c}}$. $\mathrm{Kc}$ is a dimensionless number (usually between 0.1 and 1.2) that is multiplied by the $\mathrm{ET}_{\mathrm{o}}$ value to calculate $\left(\mathrm{ET}_{\mathrm{c}}\right)$. The resulting $\mathrm{ET}_{\mathrm{c}}$ can be used to help an irrigation manager schedule when irrigation should occur and how much water should be put back into the soil. In this paper, the relation between Kc and NDVI represented by Equation (6).

$$
K_{C}=\frac{1.2}{0.6}(\mathrm{NDVI}-0.2)
$$

\subsection{Classification}

Landsat8 data were used to classify NDVI using unsupervised classification. Initial unsupervised classification (K-means) was applied which is an automated cluster analysis technique that uses a minimum spectral distance cluster algorithm to assign a pixel to a cluster of pixels with similar attribute [16].

\subsection{Penman-Montieth Method}

$\mathrm{ET}_{\mathrm{o}}$ was calculated from the meteorological data using the Penman-Montieth formula. This formula applied by empirical method to calculate $\mathrm{ET}_{0}$, which adjusted by crop coefficient to estimate $\mathrm{ET}_{\mathrm{c}}$. The meteorological parameters used in this equation were taken from Alex., Tanta, Wadi El-Natron, Cairo, Ismailia, Portsaid, El-Seuz, Helwan, Minya, Asyut, South of valley, Luxor and Aswan stations (Figure 2) shows the distribution of stations.

\section{Results and Discussion}

\subsection{Normalized Deference Vegetation Index (NDVI)}

NDVI calculated from Red and NIR bands in the satellite data. The NDVI equation produces values in the range of -1.0 to 1.0 , where vegetated areas typically have values greater than 0.2 and less values indicate non-vegetated surface features such as water, barren, ice, snow, or clouds. NDVI vary according to crop age, planting density and chlorophyll activity. It seems like $\mathrm{K}_{\mathrm{c}}$ varying from planting to senescence. NDVI used as input in Equation (6) to estimate $K_{c}$ from satellite data. Figure 3 and Figure 4 show NDVI and $K_{c}$ of Nile valley and delta.

\subsection{Reference Evapotranspiration ( $\left.\mathrm{ET}_{0}\right)$}

To solve the problem of water limitation and scarcity in Egypt, adopted policies of horizontal and vertical expanding in agricultural lands and activities had been considered based saving irrigation water to cultivate another area. Agriculture is responsible for $70 \%$ of all water use globally and water use efficiency in this sector is very low, not exceeding $45 \%$ [17]. $\mathrm{ET}_{0}$ affected directly with climate and it depend completely on meteorological data (Temperature, Relative humidity, Wind speed and Solar radiation). When vegetation covers soil $100 \%$, all water losses are transpiration. $\mathrm{ET}_{0}$ was estimated from meteorological data according to Penman-Montieth method. Mean ET $\mathrm{E}_{0}$ was $8.3(\mathrm{~mm})$. Maximum ET $\mathrm{E}_{0}$ was $10.61(\mathrm{~mm})$ at Aswan. Minimum $\mathrm{ET}_{0}$ was $6.1(\mathrm{~mm})$ at 


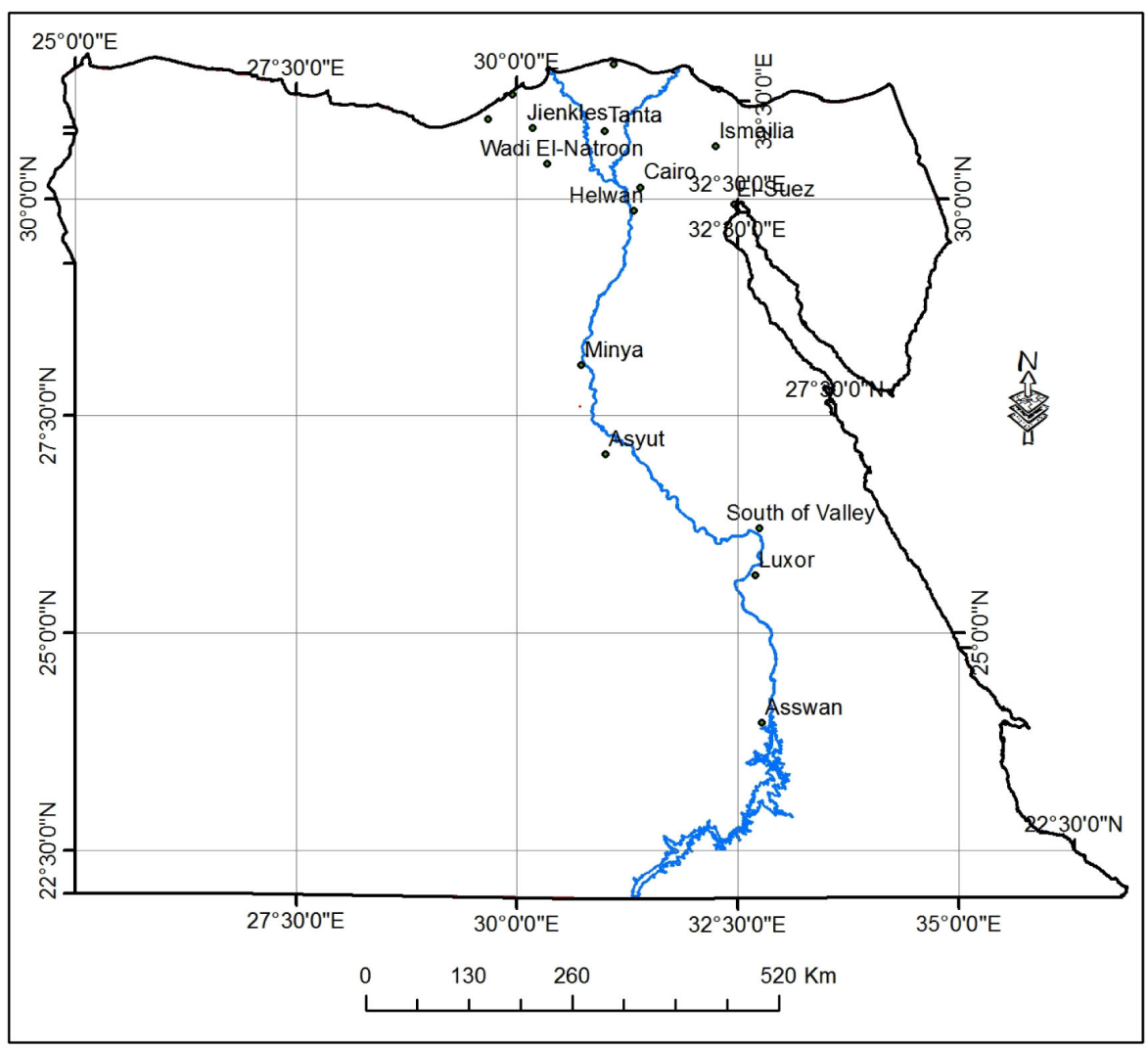

Figure 2. The distribution of meteorological stations.

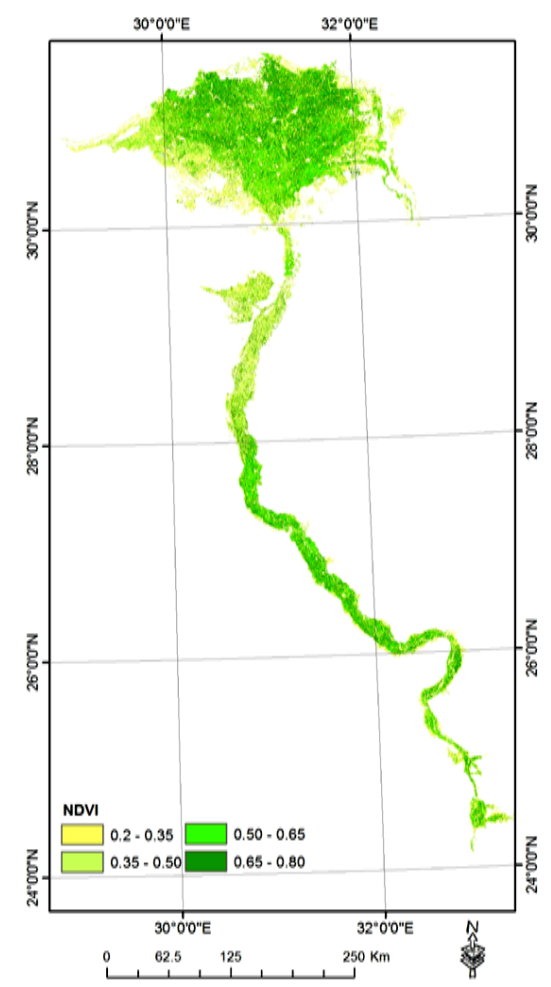

Figure 3. NDVI distribution. 


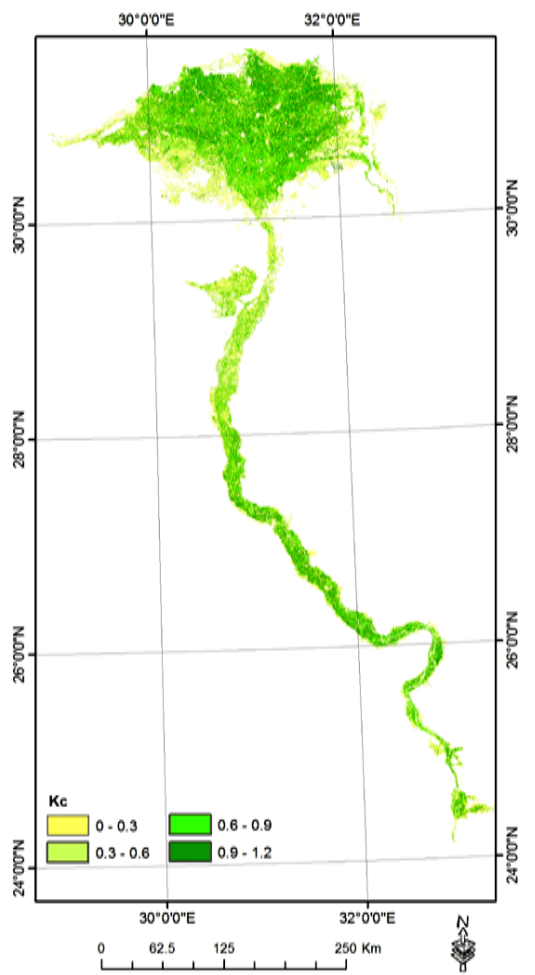

Figure 4. Kc distribution..

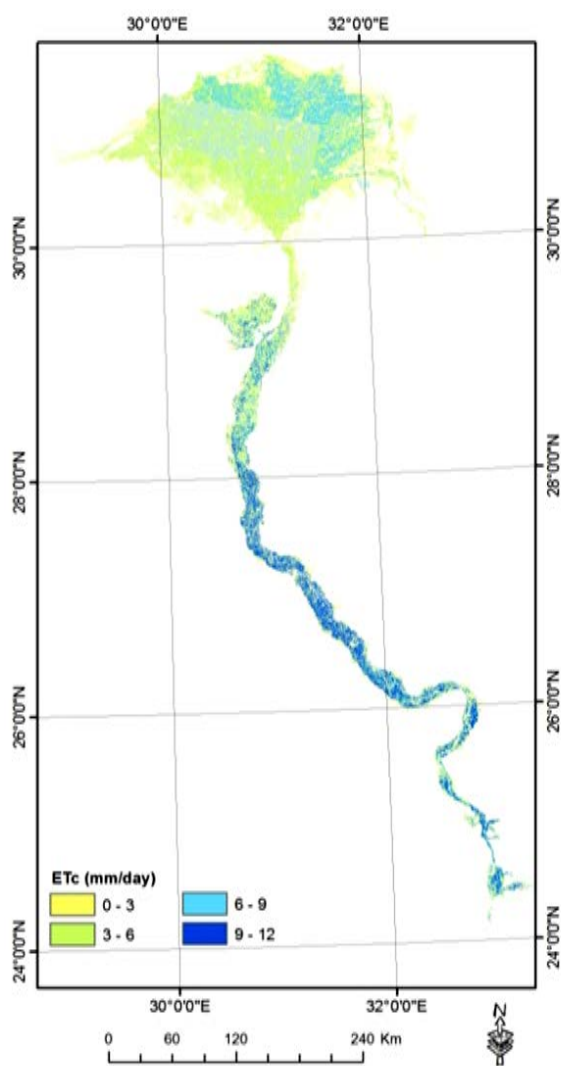

Figure 4. Kc distribution.. 
Alexandria. Comparison between monthly ETo (Alex.) and monthly ETo (Aswan) was shown in Table 2. Increase of $\mathrm{ET}_{\mathrm{o}}$ was observed in south of Egypt because of increasing of radiation and air temperature and decreasing of relative humidity.

\subsection{Crop Evapotranspiration $\left(\mathrm{ET}_{\mathrm{c}}\right)$}

$\mathrm{K}_{\mathrm{c}}$ used with $\mathrm{ET}_{\mathrm{o}}$ to estimate $\mathrm{ET}_{\mathrm{c}}$ according to Equation (1). From Figure 5, it has been observed to increase $\mathrm{ET}_{\mathrm{o}}$ in the southern part of Egypt because radiation and air temperature were high and relative humidity was low.

Table 2. $\mathrm{ET}_{\mathrm{o}}$ for Alex. at north and Aswan at south (mm/day).

\begin{tabular}{ccc}
\hline Month & ET $_{\mathbf{0}}$ (Alex.) & ET $_{\mathbf{0}}$ (Aswan) \\
\hline Jan. 2013 & 2.3 & 4.5 \\
Feb. 2013 & 3.6 & 5.9 \\
Mar. 2013 & 3.9 & 7.7 \\
Apr. 2013 & 4.5 & 9.5 \\
May 2013 & 5.1 & 10.5 \\
Jun. 2013 & 6.2 & 11.7 \\
Jul. 2013 & 6.3 & 11.1 \\
Aug. 2013 & 6.1 & 10.61 \\
Sep. 2013 & 4.9 & 10.1 \\
Oct. 2013 & 3.9 & 8.4 \\
Nov. 2013 & 2.8 & 6.1 \\
Dec. 2013 & 2.1 & 4.7 \\
Average & 4.3 & 8.4 \\
\hline
\end{tabular}

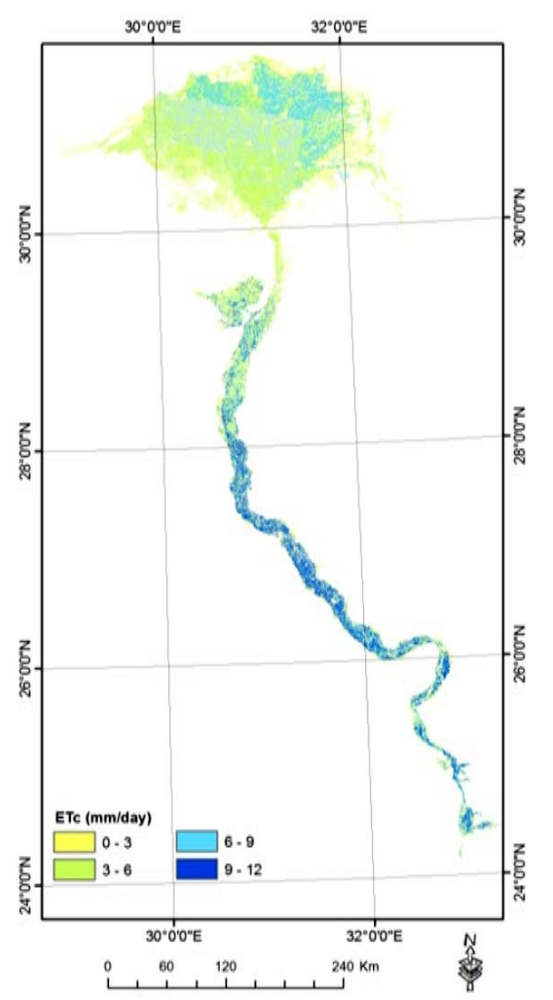

Figure 5. ETc distribution in nile valley and delta (egypt). 


\section{Conclusion}

The cultivated areas in Nile valley and delta were about 3.3 Mha. Landsat8 bands 4 and 5 used to calculate Normalized Deference Vegetation Index (NDVI). $\mathrm{K}_{\mathrm{c}}=2 *$ NDVI -0.2 represent the relation between crop coefficient $\left(\mathrm{K}_{\mathrm{c}}\right)$ and NDVI. $\mathrm{ET}_{\mathrm{o}}$ was calculated from the meteorological data using the Penman-Montieth formula. $\mathrm{K}_{\mathrm{c}}$ and $\mathrm{ET}_{\mathrm{o}}$ used to estimate $\mathrm{ET}_{\mathrm{c}}$ in Egypt. It has been observed to increase $\mathrm{ET}_{\mathrm{o}}$ in the southern part of Egypt because of radiation and air temperature were high and relative humidity was low.

\section{Acknowledgements}

I would like to thank NASA for data availability. I would like to thank my collage at NARSS, Egypt for their support and encouragement.

\section{References}

[1] Sobrino, J.A., Gomez, M., Jimenez-Munoz, J.C. and Olioso, A. (2007) Application of a Simple Algorithm to Estimate Daily Evapotranspiration from NOAA-AVHRR Images for the Iberian Peninsula. Remote Sensing of Environment, 110, 139-148. http://dx.doi.org/10.1016/j.rse.2007.02.017

[2] Magliulo, V., d'Andria, R. and Rana, G. (2003) Use of the Modified Atmometer to Estimate Reference Evapotranspiration in Mediterranean Environments. Agricultural Water Management, 63, 1-14. http://dx.doi.org/10.1016/S0378-3774(03)00098-2

[3] Yin, Y., Wu, S., Zheng, D. and Yang, O. (2008) Radiation Calibration of FAO56-Penman-Monteith Model to Estimate Reference Crop Evapotranspiration in China. Agricultural Water Management, 95, 77-84.

[4] El-Shirbeny, M.A., Aboelghar, M.A., Arafat, S.M. and El-Gindy, A.-G.M. (2014) Assessment of the Mutual Impact between Climate and Vegetation Cover Using NOAA-AVHRR and Landsat Data in Egypt. Arabian Journal of Geosciences, 7, 1287-1296.

[5] Zhao, S.H., Yang, Y.H., Zhang, F., Sui, X.X., Yao, Y.J., Zhao, N. and Li, C.Q. (2014) Rapid Evaluation of Reference Evapotranspiration in Northern China. Arabian Journal of Geosciences, 1-11.

[6] Allen, R.G., Perrier, L.S., Raes, D. and Smith, M. (1998) Crop Evapotranspiration: Guidelines for Computing Crop Requirements. Irrigation and Drainage Paper No. 56, FAO, Rome, Italy.

[7] Droogers, P. and Allen, R.G. (2002) Estimating Reference Evapotranspiration under Inaccurate Data Conditions. Irrigation and Drainage Systems, 16, 33-45. http://dx.doi.org/10.1023/A:1015508322413

[8] Hargreaves, G.H. and Samani, Z.A. (1985) Reference Crop Evapotranspiration from Temperature. Applied Engineering in Agriculture, 1, 96-99. http://dx.doi.org/10.13031/2013.26773

[9] Popova, Z., Kercheva, M. and Pereira, L.S. (2005) Validation of the FAO Methodology for Computing ETo with Limited Data. ICID 21st European Regional Conference, Frankfurt, Slubice.

[10] Doorenbos, J. and Pruitt, W.O. (1977) Crop Water Requirement: Food and Agriculture Organization of the United Nations. FAO Irrigation and Drainage Paper 24, Rome, 144.

[11] Huete, A., Didan, K., Van Leeuwen, W., Miura, T. and Glenn, E. (2008) MODIS Vegetation Indices. In Land Remote Sensing and Global Environmental Change, NASA’s Earth Observing System and the Science of ASTER and MODIS.

[12] Edward, P.G., Huete, A.R., Nagler, P.L. and Nelson, S.G. (2008) Relationship between Remotely Sensed Vegetation Indices, Canopy Attributes and Plant Physiological Processes: What Vegetation Indices Can and Cannot Tell Us about the Landscape. Sensors, 8, 2136-2160. Environment, 48, 119-126.

[13] Tasumi, M. and Allen, R.G. (2007) Satellite-Based ET Mapping to Assess Variation in ET with Timing of Crop Development. Agricultural Water Management, 88, 54-62.

[14] Ryua, S.Y., Baldocchi, D.D., Black, T.A., Dettoc, M., Lawd, B.E., Leuninge, R., Miyataf, A., Reichsteing, M., Vargash, R., Ammanni, C., Beringer, J., Flanagank, L.B., Gul, L., Hutleym, L.B., Kimn, J., McCaugheyo, H., Moorsp, E. J., Rambal, S. and Vesalar, T. (2012) On the Temporal Upscaling of Evapotranspiration from Instantaneous Remote Sensing Measurements to 8-Day Mean Daily Sums. Agricultural and Forest Meteorology, 152, 212-222. http://dx.doi.org/10.1016/j.agrformet.2011.09.010

[15] Yoder, B.J. and Waring, R.H. (1994) The Normalized Difference Vegetation Index of Small Douglas-Fir Canopies with Varying Chlorophyll Concentrations. Remote Sensing of Environment, 49, 81-91. http://dx.doi.org/10.1016/0034-4257(94)90061-2

[16] Campbell, J.B. (1996) Introduction to Remote Sensing. Taylor Francis, London. 
[17] Zhang, X., Friedl, M.A., Schaaf, C.B. and Strahler, A.H. (2004) Climate Controls on Vegetation Phenological Patterns in Northern Mid and High Latitudes Inferred from MODIS Data, Glob. Change, 10, 1133-1145.

http://dx.doi.org/10.1111/j.1529-8817.2003.00784.x 